\title{
Citalopram Hydrobromide: Degradation Product Characterization and a Validated Stability-Indicating LC-UV Method
}

\author{
Manav Sharma, Parikshit R. Jawa, Ravinder S. Gill and Gulshan Bansal* \\ Department of Pharmaceutical Sciences and Drug Research, Punjabi University, \\ Patiala, 147 002, India
}

\begin{abstract}
Cinco produtos de degradação (I-V) do hidrobromidrato de citalopram (CTL) foram formados sob condições diferentes de degradação forçada. Os produtos I e II foram formados sob condições hidrolíticas, enquanto que os produtos III-V sob condições fotolíticas. Os produtos II e IV foram encontrados como impurezas conhecidas, citalopram carboxamida e citolopram-N-óxido, respectivamente. O produto $\mathbf{I}$ foi encontrado como sendo uma nova impureza, que foi caracterizada como 3-hidroxicitalopram $\mathrm{N}$-óxido. A droga e todos os cinco produtos de degradação foram resolvidos de uma maneira otimizada em uma coluna $\mathrm{C}_{8}$ com fase móvel composta de acetonitrila e tampão acetato de amônia $\left(\mathrm{pH}^{*} 4,5\right)$ na vazão de $0,50 \mathrm{~mL} \mathrm{~min}^{-1}$. O método foi linear, preciso com $\mathrm{RSD}<3$ (desvio padrão relativo) e exato com recuperação de 88-97\% no intervalo de concentração $5-500 \mu \mathrm{g} \mathrm{mL}^{-1}$ de citalopram. Os limites de determinação (LOD) e de quantificação (LOQ) foram $1 \mu \mathrm{g} \mathrm{mL} \mathrm{L}^{-1}$ e $5 \mu \mathrm{g} \mathrm{mL}^{-1}$, respectivamente. A análise por arranjo de fotodiodo de uma solução da droga degradada contendo a droga e todos os cinco produtos de degradação revelou picos isolados, puros. Sendo assim, o método pode ser sugerido como estável.
\end{abstract}

Five degradation products (I-V) of citalopram hydrobromide (CTL) were formed under different forced degradation conditions. Products I and II were formed under hydrolytic conditions while product III-V were formed under photolytic conditions. Products II and IV were found known impurities as citalopram carboxamide and citalopram $\mathrm{N}$-oxide, respectively. Product I was found to be a new impurity which was characterized as 3-hydroxycitalopram $N$-oxide. The drug and all five degradation products were optimally resolved on a $\mathrm{C}_{8}$ column with mobile phase composed of acetonitrile and ammonium acetate buffer $\left(\mathrm{pH}^{*} 4.5\right)$ flowing at a rate of $0.50 \mathrm{~mL} \mathrm{~min}^{-1}$. The method was linear, precise RSD $<3$ (relative standard deviation) and accurate (recovery being $88-97 \%$ ) in the concentration range of $5-500 \mu \mathrm{g} \mathrm{mL}-1$ of citalopram. The limits of detection (LOD) and of quantitation (LOQ) were $1 \mu \mathrm{g} \mathrm{mL}^{-1}$ and $5 \mu \mathrm{g} \mathrm{mL} \mathrm{L}^{-1}$, respectively. The photodiode array (PDA) analysis of the degraded CTL solution containing the CTL and all five degradation products revealed each peak to be pure. Hence, the method was suggested to be stability-indicating.

Keywords: citalopram, forced degradation, liquid chromatography-mass spectrometry (LC-MS), degradation products, mass fragmentation

\section{Introduction}

Citalopram hydrobromide (CTL) (Figure 1) is a highly selective and potent serotonin reuptake inhibitor which potentiates the serotonergic activity to produce antidepressant action. ${ }^{1}$ It is also reported to reverse the memory impairment. ${ }^{2}$ Chemically, it is (RS)1-[3-(dimethylamino)propyl]-1-( $p$-fluorophenyl)-5phthalan carbonitrile. Presence of nitrile group, fused teterahydrofuran ring, and $\mathrm{C}-\mathrm{N}$ linkage in structure of the

*e-mail: gulshanbansal@ rediffmail.com drug makes it susceptible to degradation due to chemical reactivities of these groups under hydrolytic, oxidative, and photolytic environments, ${ }^{3,4}$ which will eventually produce varied impurities or degradation products. Four processrelated impurities of CTL [citalopram carboxamide (A), citalopram cyano $\mathrm{N}$-oxide (B), citalopram $\mathrm{N}$-oxide (C) and citalopram Di N-oxide (D)] reported in literature ${ }^{5}$ are listed in Figure 1. Recently, Raman et al. ${ }^{6}$ have characterized a new process-related impurity as citalopram butanone (E) (Figure1).

The International Conference on Harmonization (ICH) guidelines Q3A and Q3B require the characterization 

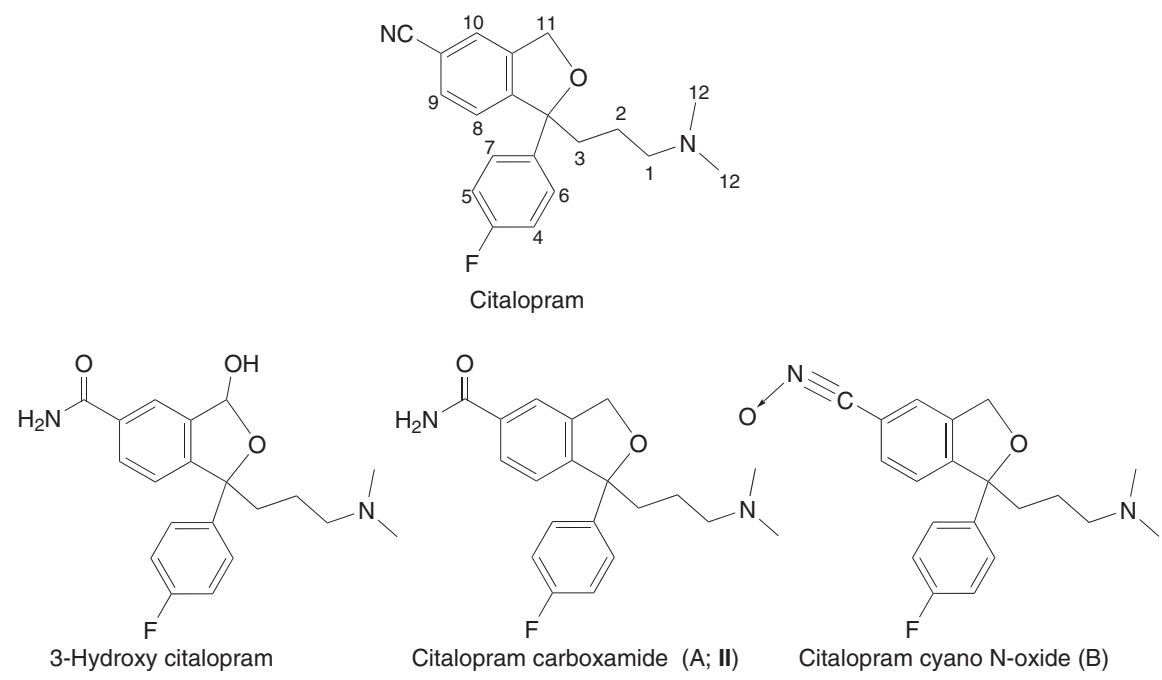

carboxamide (I)

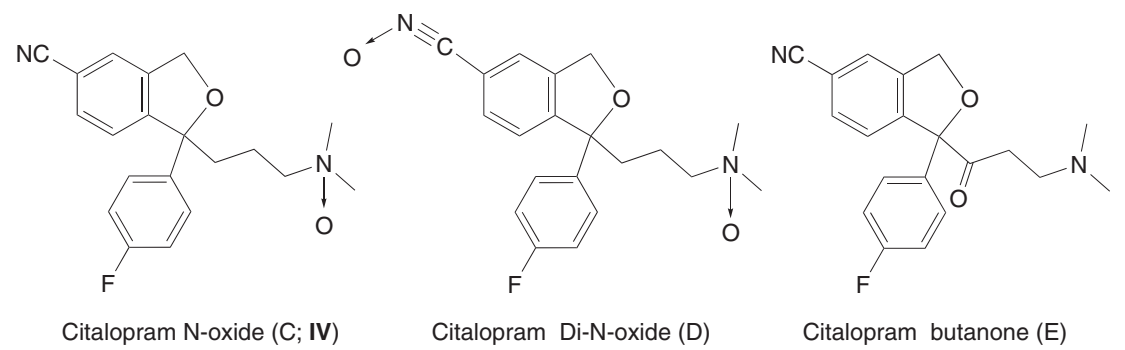

Figure 1. Citalopram and its known impurities (A-E) and degradation products (I, II and IV).

of all possible impurities and degradation products in a drug substance and product. ${ }^{7}$ Further, the ICH guidelines Q1A(R2) recommend forced degradation of the drug substance under varied conditions like hydrolysis, oxidation, heat and photolysis to generate all possible impurities or degradation products in order to facilitate their structural characterization and also in development and validation of a stability-indicating assay method (SIAM) ${ }^{8}$ However, there is no systematic forced degradation study on CTL. Moreover, spectral and mass fragmentation data of only a few process-related impurities is available in literature. ${ }^{6.9}$ Further, there are numerous analytical methods available for quantification of CTL in formulations and biological matrixes. ${ }^{10}$ Both the European Pharmacopoeia and United States Pharmacopeia have mentioned high performance liquid chromatography (HPLC) methods for separation of citalopram and some of its related substances, ${ }^{11}$ but there is no method suitable to SIAM.

Hence, the present study is undertaken to conduct ICH prescribed systematic forced degradation study on CTL to identify its potential degradation products and to develop and validate a SIAM for accurate quantification of CTL in the presence of its impurities and degradation products. The aim is to provide and substantiate the present data on impurities and quantification methods.

\section{Experimental}

\section{Chemicals and reagents}

CTL was obtained as a generous gift sample from IndSwift Laboratories Ltd. (Dera Bassi, India). Acetonitrile and methanol (both HPLC grade) and hydrochloric acid, sodium hydroxide pellets, ammonium acetate and acetic acid (all AR grade) were purchased from Ranbaxy Fine Chemicals (SAS Nagar, India). Milli-Q water obtained from Milli-Q water purification system (Synergy, Millipore, USA) in the laboratory was employed to prepare all reagents and solutions.

\section{Instrumentation}

The hydrolytic degradation studies were performed using a high-precision water bath equipped with a digital temperature controller (Narang Scientific Works, New Delhi, India) capable of maintaining temperature within $1{ }^{\circ} \mathrm{C}$. The thermal degradation study was conducted in a high precision hot air oven (Narang Scientific Works, New Delhi, India) having a temperature precision of $\pm 2{ }^{\circ} \mathrm{C}$. Photodegradation studies were performed in a photostability chamber (KBF 240; WTB Binder, Tuttlingen, 
Germany) which was equipped with a light bank consisting of two UV (OSRAM L73) and four fluorescent (OSRAM L20) lamps and capable of controlling temperature and relative humidity in the range of $\pm 2{ }^{\circ} \mathrm{C}$ and $\pm 5 \%$, respectively. The light system complied with Option 2 of the ICH guideline Q1B. ${ }^{12}$ The LC-UV (liquid chromatographyultraviolet detection) analyses were carried on an HPLC system consisted of 515 binary pumps, 2487 dual wavelength detector, Rheodyne manual injector, and Millennium 2.01 software (Waters Corp., Milford, USA). The chromatographic separations were achieved on $\mathrm{C}_{8}$ column $\left(150 \mathrm{~mm} \times 4.6 \mathrm{~mm}\right.$ i.d., $5 \mu \mathrm{m}$, Spherisorb ${ }^{\circledR}$ ) (Waters Corp., Milford, USA). A Nucleosil $\mathrm{C}_{8}(8 \mathrm{~mm} \times 4.6 \mathrm{~mm}$ i.d. $)$ guard column was placed before the analytical column. The photodiode array (PDA) analysis was performed on an HPLC system consisting of a $600 \mathrm{E}$ pump, 996 PDA detector, 717 autoinjector and degasser module (Waters Corp., Milford, USA). The liquid chromatography-mass spectrometry (LC-MS) studies and mass spectral analyses were performed in positive electrospray ionization (+ESI) mode using a Bruker Daltonics GmbH microTOF instrument (Bremen, Germany) controlled by microTOF control software version 2.0. The LC system of LC-MS was an 1100 series liquid chromatograph (Agilent Technologies Inc., Wilmington, USA), controlled by Hystar (version 3.1) software. The column used for LC-MS studies was the same as that for LC-UV analyses. Fourier transform infrared (FT-IR) spectra were recorded using 1711 Perkin Elmer IR spectrophotometer (Shelton, CT, USA) while the nuclear magnetic resonance of ${ }^{1} \mathrm{H}$ (NMR spectrum) was recorded on Avance II 400 spectrophotometer (Bruker, Fallanden, Switzerland).

\section{Forced decomposition study}

The drug was subjected to hydrolytic degradation in $2 \mathrm{~mol} \mathrm{~L}^{-1} \mathrm{HCl}$, water and $0.2 \mathrm{~mol} \mathrm{~L}^{-1} \mathrm{NaOH}$ at $85^{\circ} \mathrm{C}$ over $48 \mathrm{~h}$. The oxidative degradation was performed in $30 \%$ $\mathrm{H}_{2} \mathrm{O}_{2}$ solution at room temperature over $48 \mathrm{~h}$. For thermal degradation, the solid drug was sealed in amber coloured borosilicate glass vials, which were maintained at $50^{\circ} \mathrm{C}$ for 31 days. The photolytic studies were performed by exposing solid drug spread as a thin layer in Petri-plates as well as drug solutions in $2 \mathrm{~mol} \mathrm{~L}^{-1} \mathrm{HCl}$, water, and $0.01 \mathrm{~mol} \mathrm{~L}^{-1} \mathrm{NaOH}$ in borosilicate vials to the light in the photostability chamber for 16 days during which the total light exposure was $1.2 \times 10^{6}$ lux. A parallel set of solid drug and drug solutions was kept in dark chamber for the same period to serve as dark control. The drug concentration in all solution phase studies was $0.1 \% \mathrm{~m} / \mathrm{v}$. Samples were withdrawn at zero time and at prefixed time intervals. Whenever necessary, they were neutralized by acid or alkali and diluted up to 10 times with mobile phase before injection.

\section{Chromatographic conditions}

The drug and all degradation products formed under different forced conditions were optimally resolved on $\mathrm{C}_{8}$ column $\left(150 \mathrm{~mm} \times 4.6 \mathrm{~mm}\right.$ i.d., $5 \mu \mathrm{m}$, Spherisorb $\left.{ }^{\circledR}\right)$ with a mobile phase composed of acetonitrile and ammonium acetate buffer $\left(0.025 \mathrm{~mol} \mathrm{~L}^{-1}\right)\left(35: 65 \mathrm{v} / \mathrm{v}, \mathrm{pH}^{*} 4.5\right)$ at a flow rate of $0.50 \mathrm{~mL} \mathrm{~min}^{-1}$. The injection volume was $20 \mu \mathrm{L}$, and the eluent was monitored at $240 \mathrm{~nm}$. The method was validated for its stability-indicating nature. Appropriate blank was injected before each analysis.

\section{Isolation and characterization of degradation product}

The major degradation product (II) formed in $0.1 \mathrm{~mol} \mathrm{~L}^{-1} \mathrm{NaOH}$ after refluxing at $85^{\circ} \mathrm{C}$ for $35 \mathrm{~h}$ was isolated as fine crystals after neutralizing the solution with $0.1 \mathrm{~mol} \mathrm{~L}^{-1} \mathrm{HCl}$ and cooling the reaction solution in refrigerator for $24 \mathrm{~h}$. The crystals were filtered, washed with cold water, and dried in a vacuum desiccator. Purity of the product was ascertained by the optimized chromatographic method. Its structure was ascertained by comparing its FT-IR, ${ }^{1} \mathrm{H}$ NMR and mass spectral data with that of the drug. The other degradation products formed in sufficient amounts were characterised through LC-PDA and LC-MS studies (in both -ESI and +ESI modes, i.e. negative and positive ion modes) using a mixed degraded sample which was prepared by mixing drug solutions subjected to different forced conditions so that all degradation products were present in one solution.

\section{Method validation}

The optimized method was validated by evaluating linearity, precision, accuracy, limit of detection (LOD), limit of quantitation (LOQ), selectivity and ruggedness as per ICH guidelines Q2(R1). ${ }^{13}$

\section{Linearity and range}

A stock solution of CTL $\left(1 \mathrm{mg} \mathrm{mL} \mathrm{mL}^{-1}\right)$ in water was prepared in triplicate and each solution was serially diluted with mobile phase to prepare standard solutions having concentrations in the range of 5 to $500 \mu \mathrm{g} \mathrm{mL}^{-1}$. Each set of stock and standard solutions was analyzed using the optimized chromatographic conditions to generate three calibration plots in order to select the concentration range providing maximally linear relationship with the response. 


\section{Precision}

The intra-day precision was evaluated by analysing $(n=6)$ each of the three drug concentrations (40, 80 and $160 \mu \mathrm{g} \mathrm{mL}^{-1}$ ) on the same day. The same drug concentrations were analysed on three different days to evaluate inter-day precision. The precisions were expressed as percent relative standard deviation (\% RSD) of the calculated concentrations.

\section{Accuracy}

The photodegraded drug solutions in acidic and alkaline media were mixed in equal proportions to prepare a mixed degraded solution. The later was mixed further mixed with equal volume of mobile phase to prepare unfortified sample solution. It was also mixed separately with an equal volume of each of the three standard drug solutions (80, 160 and $320 \mu \mathrm{g} \mathrm{mL}^{-1}$ ) so that the drug concentrations in the mixed solution was fortified by $40,80,160 \mu \mathrm{g} \mathrm{mL}^{-1}$, respectively. The unfortified and each of the fortified solutions was prepared and analysed in triplicate. The accuracy was expressed a percent recovery of the drug from the fortified solutions vis-à-vis unfortified solution.

\section{$L O D, L O Q$ and selectivity}

The LOD and LOQ of the drug was determined by signal-to-noise ratio method by measuring signals from samples with known low concentrations of drug (0.5, 1.0, $5.0 \mu \mathrm{g} \mathrm{mL}^{-1}$ for LOQ and $0.25,0.50,1.0 \mu \mathrm{g} \mathrm{mL}^{-1}$ for LOD). The signals were compared with those of blank to establish the minimum concentration at which the analyte was reliably detected or quantified. The overall selectivity was established through determination of purity and resolution factor of each degradation product peak using a PDA detector.

\section{Robustness}

Various chromatographic parameters including flow rate, detection wavelength, and mobile phase composition were slightly varied deliberately and the mixed degraded solution was analysed $(n=3)$ using optimized as well as each varied chromatographic conditions. The calculated drug concentration obtained through each varied conditions was compared with that obtained through the optimized conditions.

\section{Results and Discussion}

\section{Development of SIAM}

Initially a standard drug solution and drug solutions subjected to varied forced degradation conditions were chromatographed on a $\mathrm{C}_{18}$ column $(150 \mathrm{~mm} \times 4.6 \mathrm{~mm}$ i.d., Spherisorb $\left.{ }^{\circledR}\right)$ with mobile phase composed of phosphate buffer (0.02 $\left.\mathrm{mol} \mathrm{L}^{-1}, \mathrm{pH} 3.0\right)$ and acetonitrile (60:40 v/v) flowing at a rate of $0.8 \mathrm{~mL} \mathrm{~min}^{-1}$ using $240 \mathrm{~nm}$ as detection wavelength. The drug eluted at $4.5 \mathrm{~min}$ but degradation products formed under different conditions were not resolved. The phosphate buffer was replaced with ammonium acetate buffer to make the method LC-MS compatible, and flow rate was decreased to $0.4 \mathrm{~mL} \mathrm{~min}^{-1}$ to resolve the degradation products. It eluted the drug at 19.1 min but degradation products formed in photodegraded drug solution in $2 \mathrm{~mol} \mathrm{~L}^{-1} \mathrm{HCl}$ were not resolved. To optimize the chromatographic conditions for separation of drug and all degradation products in a single isocratic run, the mixed degraded solution was employed so that all degradation products were present in one solution. Numerous alterations in flow rate and mobile phase compositions did not improved resolution of the degradation products. Even use of ternary mobile phase composed of buffer ( $\mathrm{pH}$ 3.0), acetonitrile, and methanol in varied proportions did not resolve the degradation products.

A critical analysis of structure of the drug followed by prediction of various degradation products based on chemical reactivities of the drug molecule under varied forced degradation conditions and various chromatograms obtained during the method development process suggested that the possible degradation products are polar than the drug itself. Further, differences in polarities of these degradation products were expected to be very small which is responsible for very close elution of these products. Based on this hypothesis, it was predicted that elution of the degradation products may be delayed by increasing polarity of stationary phase. Hence, $\mathrm{C}_{18}$ column was replaced by $\mathrm{C}_{8}$ column $\left(150 \mathrm{~mm} \times 4.6 \mathrm{~mm}\right.$ i.d., $5 \mu \mathrm{m}$, Spherisorb $\left.{ }^{\circledR}\right)$ which was run over by mobile phase composed of ammonium acetate solution $\left(0.02 \mathrm{~mol} \mathrm{~L}^{-1}\right)$ and acetonitrile (40:60, $\mathrm{pH}^{*} 6.0$ ) at a rate of $1 \mathrm{~mL} \mathrm{~min}^{-1}$. The drug eluted at $19 \mathrm{~min}$ but degradation products were noted as merged peaks ahead of the drug peak. Lowering of $\mathrm{pH}^{*}$ to 5.5 increased the sharpness of peaks. Increase in proportion of aqueous phase to $65 \%$ and further lowering the $\mathrm{pH}^{*}$ to 4.5 improved the resolution with the drug eluting at $34 \mathrm{~min}$. Further increase in aqueous component dashaped the peaks and also delayed drug elution to $80 \mathrm{~min}$. Increase in concentration of ammonium acetate from 0.02 to $0.025 \mathrm{~mol} \mathrm{~L}^{-1}$ resulted in a highly resolved chromatogram with all peaks well separated from each other. Hence, the optimum isocratic separation of drug and degradation products was achieved on $\mathrm{C}_{8}$ column $\left(150 \mathrm{~mm} \times 4.6 \mathrm{~mm}\right.$ i.d., $5 \mu \mathrm{m}$, Spherisorb $\left.{ }^{\circledR}\right)$ with mobile phase composed of ammonium acetate $\left(0.025 \mathrm{~mol} \mathrm{~L}^{-1}\right)$ and acetonitrile $\left(65: 35, \mathrm{pH}^{*} 4.5\right)$ at a flow 


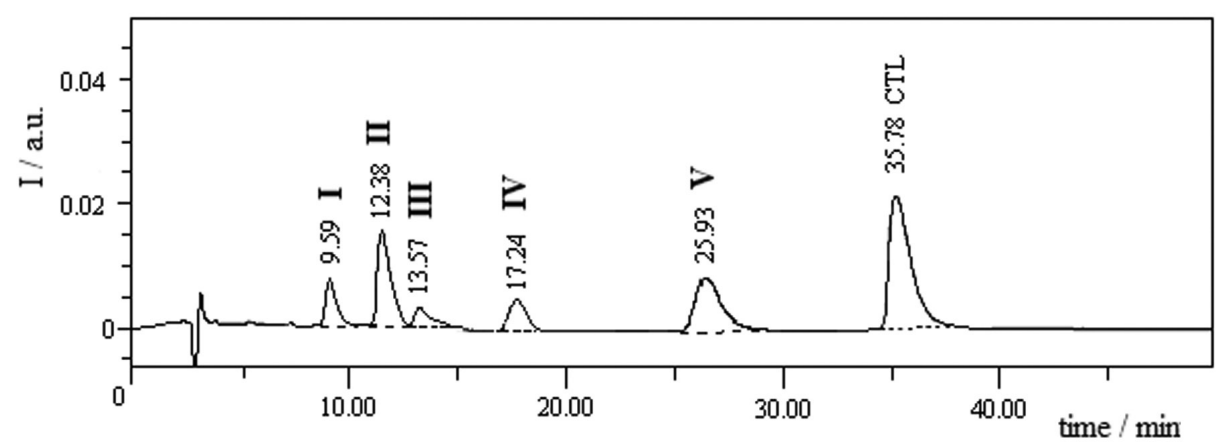

Figure 2. LC chromatogram showing separation of CTL and its all degradation products (I-V) in a single isocratic run.

rate of $0.5 \mathrm{~mL} \mathrm{~min}^{-1}$ using $240 \mathrm{~nm}$ as detection wavelength. A typical chromatogram of mixture sample is shown in Figure 2. PDA analysis of the mixed solution established the purity of drug and each degradation product peak which indicated the method to be a selective SIAM. The method was applied to analyse samples generated under each forced degradation condition to study degradation behaviour of the drug.

\section{Forced degradation behaviour}

In total, five peaks due to degradation products (I-V) formed under different forced degradation conditions were noted in the chromatograms (Figure 3). Chromatogram of standard solution of drug showed the drug peak (CTL) at $36.67 \mathrm{~min}$ along with a small impurity peak (II) at 12.41 min (Figure 3A). The latter was also noted as degradation product in all forced degradation conditions except in oxidative medium. The drug degraded almost completely (98.99\%) to product II in $0.1 \mathrm{~mol} \mathrm{~L}^{-1} \mathrm{NaOH}$ at $85{ }^{\circ} \mathrm{C}$ after just $0.5 \mathrm{~h}$. The extent of degradation was significantly decreased in $0.01 \mathrm{~mol} \mathrm{~L}^{-1} \mathrm{NaOH}$ (about $28 \%$ after $4 \mathrm{~h}$ ) and another product I was formed which eluted at $9.58 \mathrm{~min}$ (Figure 3B). The rate of degradation was comparatively much lower in acidic medium (about $41 \%$ in $2 \mathrm{~mol} \mathrm{~L}^{-1} \mathrm{HCl}$ at $85^{\circ} \mathrm{C}$ after $48 \mathrm{~h}$ ) wherein product II was formed in minute amount along with product I (Figure 3C). Insignificant degradation $(<3 \%)$ was noted in water at $85{ }^{\circ} \mathrm{C}$ (Figure 3D) and in oxidative condition after $48 \mathrm{~h}$ (Figure 3E). Exposure of the drug in dry state to temperature of $50{ }^{\circ} \mathrm{C}$ (Figure 3F) and UV-Vis light (Figure $3 \mathrm{G}$ ) resulted in neither any increase in peak area of II nor formation of any other product which suggested that the drug in solid state was stable to heat and light. However, rate and pattern of degradation under photolytic conditions was significantly different from that under hydrolytic conditions. The rate of degradation in all media under photolytic condition was accelerated. No product other than I and II was formed in water (Figure 3H) while products III ( $\mathrm{R}_{\mathrm{T}} 13.75 \mathrm{~min}$, i.e. retention time) and IV $\left(\mathrm{R}_{\mathrm{T}} 17.52 \mathrm{~min}\right)$ in addition to $\mathbf{I}$ and $\mathbf{I I}$ were formed in alkaline medium (Figure 3I). A new product $\mathbf{V}\left(\mathrm{R}_{\mathrm{T}} 26.33 \mathrm{~min}\right)$ was formed along with products $\mathbf{I}, \mathbf{I I}$ and $\mathbf{I V}$ in acidic medium (Figure 3J). The peak area of product $\mathbf{I}$ in all media under photolytic conditions was greater than under hydrolytic conditions. It suggested that formation of I was accelerated by light. Further, formation of products III-V in acidic and alkaline media upon exposure to light in solution state indicated that the drug is photosensitive.

\section{Characterization of degradation products}

The degradation products I, II and IV were characterized (Figure 1) through spectral analyses and LC-MS studies. The major product (II), formed in all forced conditions was isolated from alkali decomposition solution. The comparative FT-IR spectral data of drug and II (Table 1) revealed absence of $-\mathrm{C} \equiv \mathrm{N}$ stretching band at $2238 \mathrm{~cm}^{-1}$ in II indicating that nitrile group was absent. Appearance of bands at $3393 \mathrm{~cm}^{-1}$ for $\mathrm{N}-\mathrm{H}$ stretch, $1601 \mathrm{~cm}^{-1}$ for $\mathrm{C}=\mathrm{O}$ stretch (amide I band) and $1559 \mathrm{~cm}^{-1}$ for $\mathrm{N}-\mathrm{H}$ bend (amide II band) suggested an amide functionality in II. The C-F stretching and aliphatic $\mathrm{C}-\mathrm{H}$ bending vibrations were noted in both CTL and II. Comparison of ${ }^{1} \mathrm{H}$ NMR spectra of the

Table 1. Comparative FT-IR data of CTL and II

\begin{tabular}{lcc}
\hline Vibrational band & \multicolumn{2}{c}{ Assignment $\left(\mathrm{cm}^{-1}\right)$} \\
\cline { 2 - 3 } & II & CTL \\
\hline N-H str. (-CONH-) & 3393 & absent \\
C-H str. (aromatic) & 3067,3041 & 3090,3062 \\
C-H str. (aliphatic) & 2956,2871 & 2963,2853 \\
C $\equiv \mathrm{N}$ str. & Absent & 2238 \\
$\mathrm{C}=\mathrm{O}$ (-CONH-) & 1601 & absent \\
N-H bend & 1559 & absent \\
CH bend & 1482 & 1487 \\
C-F stretching & 1384 & 1390 \\
\hline
\end{tabular}



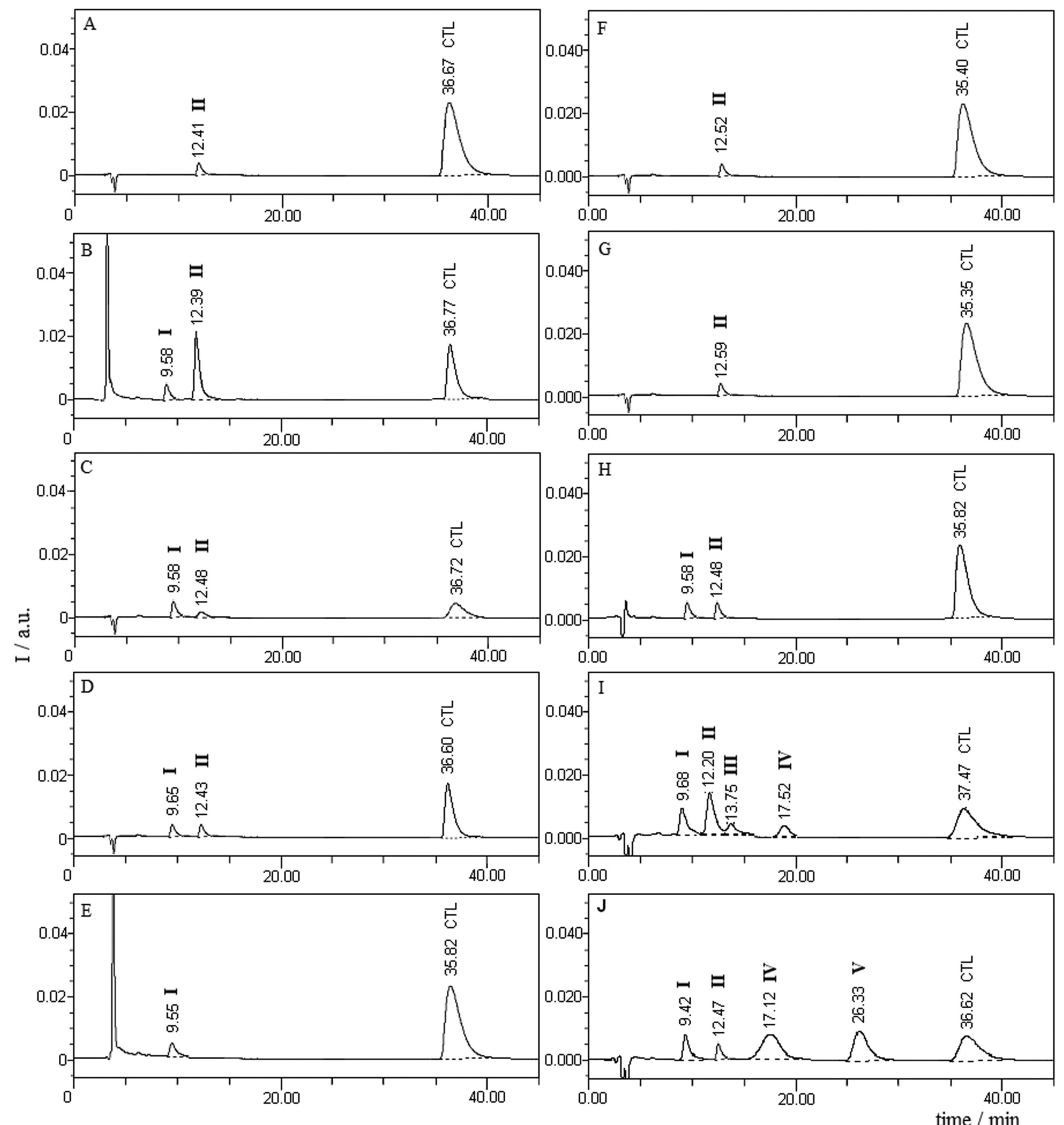

Figure 3. LC chromatograms of standard solution of the drug (A), drug subjected to alkaline hydrolysis (B), acid hydrolysis (C), neutral hydrolysis (D), oxidation (E), dry heat (F) and drug subjected to photodegradation in dry state (G), in water (H), in alkali (I) and in acid (J).

drug and II (Table 2) revealed that all signals in spectrum of II were almost similarly placed as in that of CTL except an additional 2 proton singlet at $\delta 7.62$ which disappeared upon $\mathrm{D}_{2} \mathrm{O}$ exchange. It supported the presence of an amide group as also suggested by FT-IR spectra. The mass spectra of CTL and II (Figures 4A and 4B) in +ESI mode showed the parent molecules as $\mathrm{M}+1$ peaks at $\mathrm{m} / \mathrm{z} 324.54$ and $\mathrm{m} / \mathrm{z}$ 343.40 corresponding to molecular masses of 324 and 342, respectively. The even molecular mass of II indicated even number of nitrogen atoms in the molecule similar to the drug. Increase in 18 units in mass of II vis-à-vis drug was attributed to addition of water which was possible under all hydrolytic conditions due to hydrolysis of $\mathrm{C} \equiv \mathrm{N}$ group. Further, the $\mathrm{MS}^{2}$ scan of II (Figure 5B) showed a fragment at $m / z, 325.81$ due to loss of $17 \mathrm{amu}$ which could be formed by loss of $\mathrm{NH}_{3}$ from the parent ion $(\mathrm{m} / 2343.40)$. It affirmed 
Table 2. Comparative ${ }^{1} \mathrm{H}$ NMR spectral data of CTL and II

\begin{tabular}{|c|c|c|c|c|}
\hline \multirow[t]{2}{*}{ Proton* } & \multicolumn{2}{|c|}{ CTL } & \multicolumn{2}{|c|}{ II } \\
\hline & $\delta$ value & Description & $\delta$ value & Description \\
\hline 1 & 3.14 & $2 \mathrm{H}, \mathrm{t}, J 7.6 \mathrm{~Hz}$ & 2.76 & $2 \mathrm{H}, \mathrm{t}, J 7.6 \mathrm{~Hz}$ \\
\hline 2 & $1.78-1.65$ & $2 \mathrm{H}, \mathrm{m}$ & $2.18-2.14$ & $2 \mathrm{H}, \mathrm{m}$ \\
\hline 3 & $2.46-2.30$ & $2 \mathrm{H}, \mathrm{m}$ & $2.30-2.23$ & $2 \mathrm{H}, \mathrm{m}$ \\
\hline 4,5 & $7.54-7.50$ & $2 \mathrm{H}, \mathrm{m}$ & $7.49-7.45$ & $2 \mathrm{H}, \mathrm{m}$ \\
\hline 6,7 & $7.06-7.01$ & $2 \mathrm{H}, \mathrm{m}$ & $6.97-7.02$ & $2 \mathrm{H}, \mathrm{m}$ \\
\hline 8 & 7.57 & $1 \mathrm{H}, \mathrm{s}$ & 7.34 & $1 \mathrm{H}, \mathrm{d}, J 8.0$ \\
\hline 9 & 7.63 & $1 \mathrm{H}, \mathrm{s}$ & 7.84 & $1 \mathrm{H}, \mathrm{d}, J 8.0$ \\
\hline 10 & 7.64 & $1 \mathrm{H}, \mathrm{d}, J_{\text {allylic }} 0.8 \mathrm{~Hz}$ & 7.64 & $1 \mathrm{H}, \mathrm{s}$ \\
\hline $11 \mathrm{a}$ & 5.27 & $1 \mathrm{H}, \mathrm{d}, J_{\mathrm{gem}} 13.0 \mathrm{~Hz}$ & 5.19 & $1 \mathrm{H}, \mathrm{d}, J_{\mathrm{gem}} 13.0 \mathrm{~Hz}$ \\
\hline $11 b$ & 5.15 & $1 \mathrm{H}, \mathrm{d}, J_{\mathrm{gem}} 13.0 \mathrm{~Hz}$ & 5.09 & $1 \mathrm{H}, \mathrm{d}, J_{\mathrm{gem}} 13.0 \mathrm{~Hz}$ \\
\hline 12 & 2.76 & $6 \mathrm{H}, \mathrm{s}$ & 2.47 & $6 \mathrm{H}, \mathrm{s}$ \\
\hline$-\mathrm{CONH}_{2}$ & - & - & 7.62 & $2 \mathrm{H}, \mathrm{s}$ \\
\hline
\end{tabular}

* Refer to Figure 1 for proton assignments.
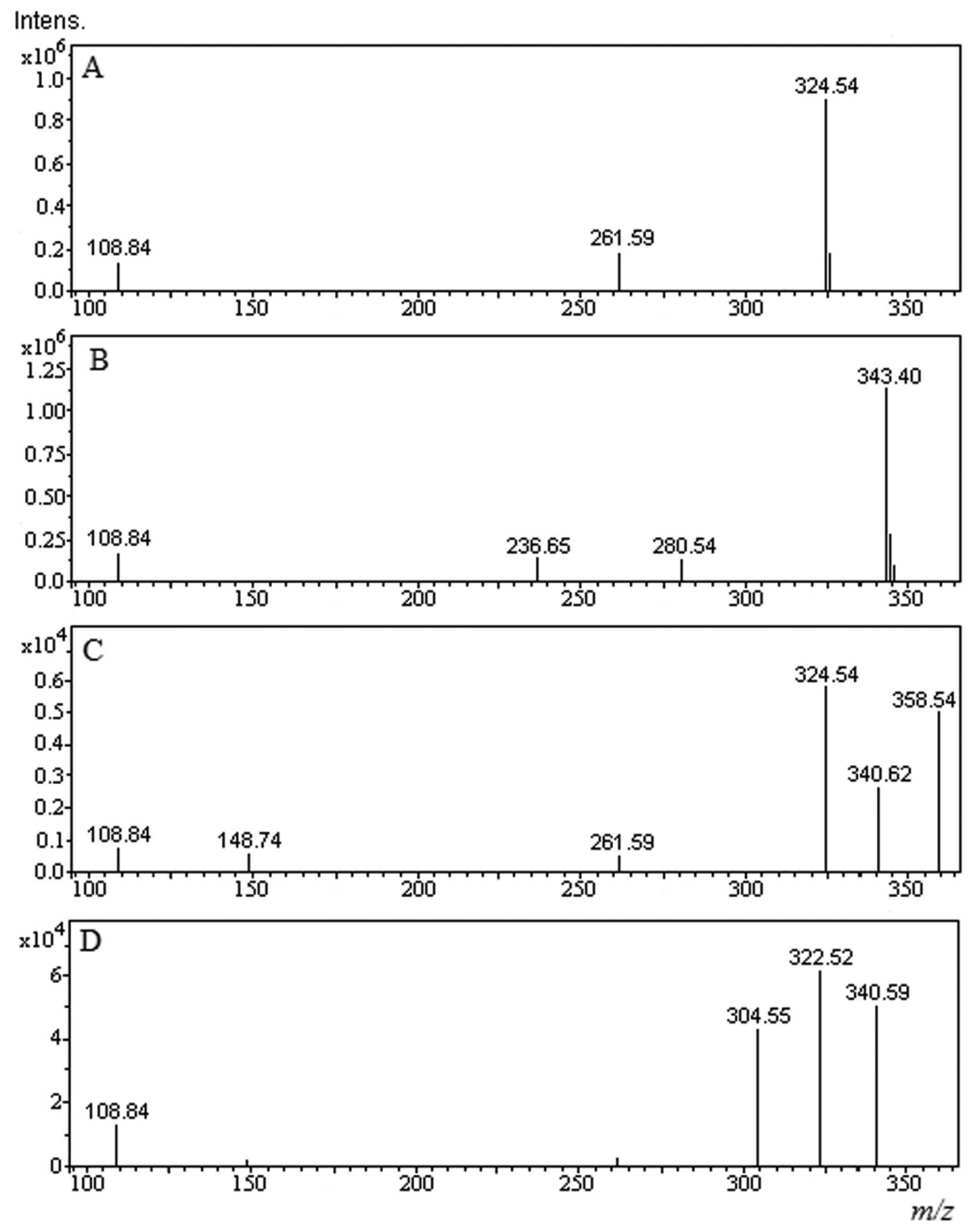

Figure 4. MS scans of CTL (A), product II (B), and LC-MS scans of product I (C) and product IV (D). 

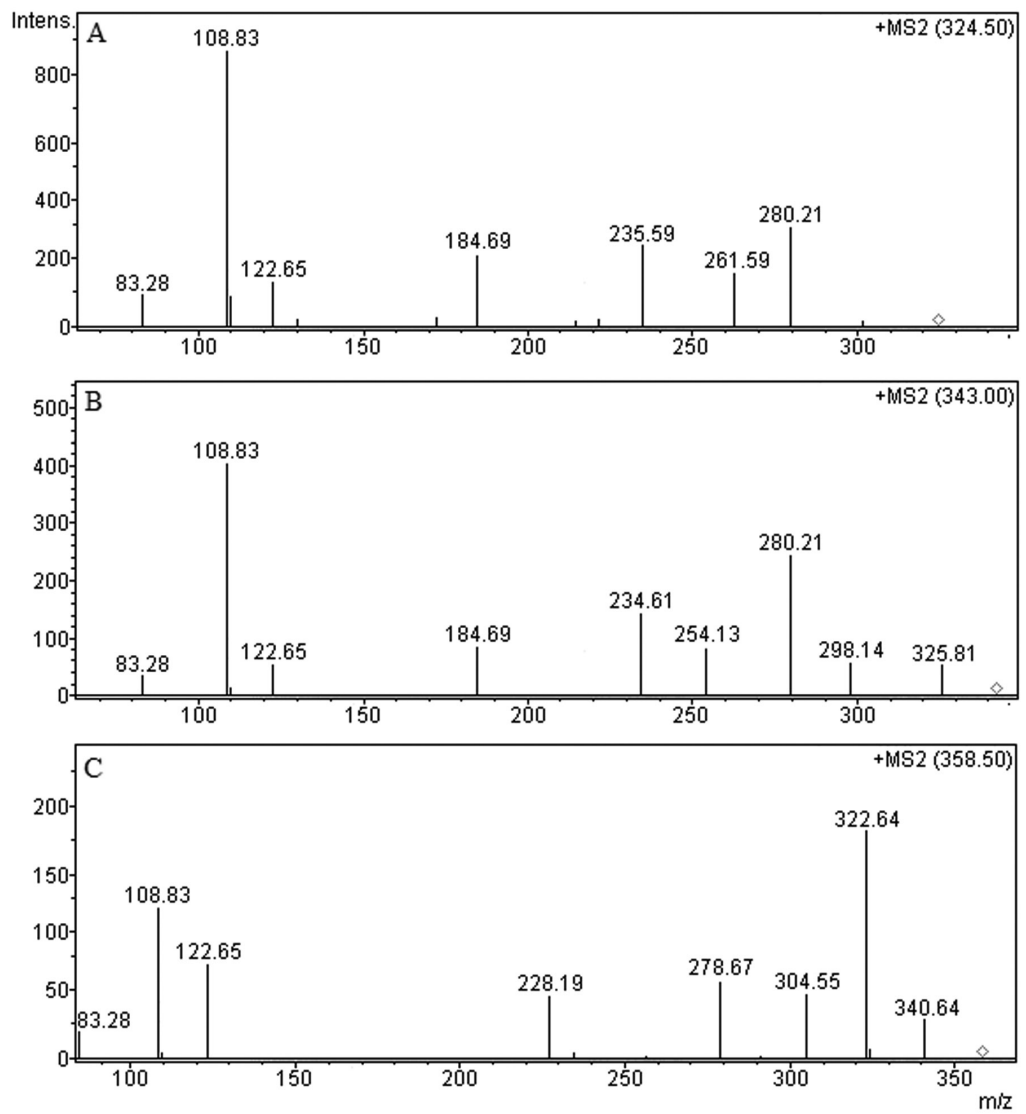

Figure 5. $\mathrm{MS}^{2}$ scans of CTL (A), product II (B) and LC-MS ${ }^{2}$ scan of product I (C).

the presence of a primary amino group in II. Based on these results, the product II was suggested to be formed through hydrolysis of nitrile group to amide without any other change in the drug molecule. It was confirmed by comparative mass fragmentation pattern of CTL and II (Figure 6) proposed on the basis of their MS and $\mathrm{MS}^{2}$ scans (Figures 4 and 5). The $\mathrm{MS}^{2}$ scan of CTL (Figure 4A) showed fragment peaks at $\mathrm{m} / \mathrm{z} 2280,262,236,185,123,109$ and 83. The peaks at $\mathrm{m} / z 262$ and 109 were observed similarly as in a study by Mullera et al. ${ }^{14}$ The fragmentation pattern of CTL was conveniently proposed (Figure 6) revealing that fragmentation was triggered by protonation on either nitrogen of dimethylamino or oxygen of benzofuranyl moieties. The heaviest fragment at $\mathrm{m} / \mathrm{z} 280$ was formed by loss of dimethylamine (45 amu) from the parent ion $(\mathrm{m} / \mathrm{z} 325)$ similar to that reported by Raman et al. ${ }^{6}$ The fragment of $\mathrm{m} / \mathrm{z}$ 262 was formed either directly from the parent ion ${ }^{6}$ or from $\mathrm{m} / \mathrm{z} 280$ by loss of a $\mathrm{H}_{2} \mathrm{O}$ molecule through rearrangement. Loss of an acetylene molecule (26 amu) from tropyllium ion of $m / z, 262$ is proposed to produce fragment of $m / z 236$, which finally loose $\mathrm{CH} \equiv \mathrm{C}-\mathrm{C} \equiv \mathrm{N}$ to give fragment of $\mathrm{m} / z 185$. The base peak $(\mathrm{m} / \mathrm{z}, 109)$ and other peaks were proposed to form by another fragmentation pathway involving oxygen of benzofuran. The $\mathrm{MS}^{2}$ scan of product II (Figure 5B) showed fragment peaks at $m / z 298,280,254,235,185,123,109$ and 83. The fragment of $\mathrm{m} / z 298,280$ and 254 were formed from II (parent ion $\mathrm{m} / \mathrm{z}$ 343) similarly as fragments of $\mathrm{m} / \mathrm{z}, 280$, 262 and 236 were formed from the drug. The fragment of $\mathrm{m} / \mathrm{z}, 185$ was formed from $\mathrm{m} / \mathrm{z} 236$ by loss of $\mathrm{CH} \equiv \mathrm{C}-\mathrm{C} \equiv \mathrm{N}$ similar to the drug. It supported that the tertiary amino moiety was intact. Formation of fragments of $m / z, 109,123$ and 83 in both the drug and II by the same fragmentation pathway suggested that no change occurred in the $p$-fluorophenyl ring of the drug molecule. Fragment of $m / z, 235$ which could only be formed by loss of ammonia and subsequent loss of CO (2 amu) to produce fragment of $\mathrm{m} / \mathrm{z} 298$ confirmed the presence of $-\mathrm{CONH}_{2}$ group in II. Hence the product II was characterized as 1-(3-dimethylaminopropyl)-1-(4fluorophenyl)-1,3-dihydro-isobenzofuran-5-carboxamide (citalopram carboxamide) which is a known impurity of CTL (Figure 1).

\section{LC-PDA and LC-MS studies}

UV absorbance spectra of each peak obtained through PDA analysis revealed that drug and all five degradation products have almost same wavelength maxima $(240 \pm 5 \mathrm{~nm})$. It suggested that chromophore in the drug was retained in 


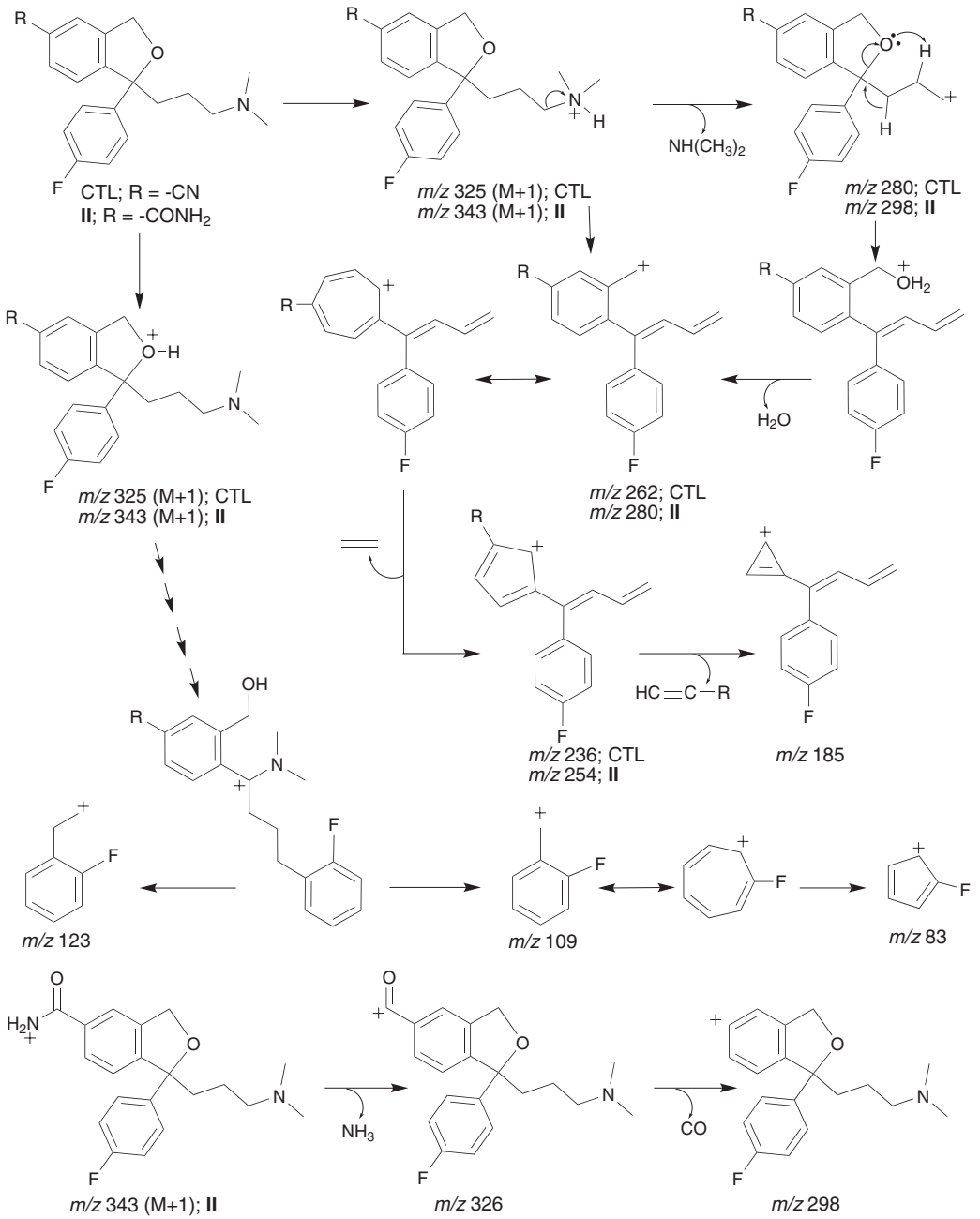

Figure 6. Proposed common mass fragmentation pattern of CTL and product II.

the degradation products. For characterization of degradation products I, III, IV and $\mathbf{V}$, the mixed degraded solution was subjected to LC-MS studies in the +ESI mode. Products III and $\mathbf{V}$ were not detected in the LC-MS chromatogram probably due to poor ionizability or trace concentrations. Change in ionization mode from +ESI to -ESI, numerous variations in ionization conditions including end plate offset, capillary voltage, collision cell RF, nebulizer pressure, dry gas flow rate, and dry temperature in both -ESI and +ESI modes, and even use of concentrated degraded solutions did not help detection of these analytes, in LC-MS chromatograms. Hence, these were not characterized in the present study. The line spectra obtained through LC-MS analysis of products I and IV (Figures 4C and 4D) showed the parent ion peaks $(\mathrm{M}+1)$ at $\mathrm{m} / \mathrm{z} 358.54$ and 340.59 , respectively indicating their molecular masses being 358 and 340 , respectively. Their structures were proposed based on their mass values, mass fragmentation pattern, and known chemical reactivities of different functional groups present in CTL in different media. ${ }^{3,4}$
Product I was formed in acidic medium under photolytic as well as hydrolytic conditions. Its even molecular mass (358 amu) indicated even number of nitrogen atoms in it (The Nitrogen Rule). Its structure was characterized through mass fragmentation pattern (Figure 7) proposed through its LC-MS scans. Increase in molecular mass of $\mathbf{I}$ by $34 \mathrm{amu}$ with respect to CTL could be attributed to addition of a water molecule (18 amu) and an oxygen atom $(16 \mathrm{amu})$ in the drug molecule. Addition of water was justified due to hydrolysis of $-\mathrm{C} \equiv \mathrm{N}$ group in the drug under hydrolytic conditions to form $-\mathrm{CONH}_{2}$. Formation of I under photolytic conditions also suggested addition of oxygen atom to form $\mathrm{N}$-oxide in the first instance. But it is not expected because $\mathbf{I}$ is also formed under hydrolytic conditions. The furan ring is reported to be under substitution reaction to form hydroxyfuran through hydroperoxide intermediate in aqueous medium in the presence of air. ${ }^{4}$ Hence, the lone oxygen atom is suggested to be substituted on the furan ring as $-\mathrm{OH}$ group. This proposition is supported by fragment peaks in LC-MS 


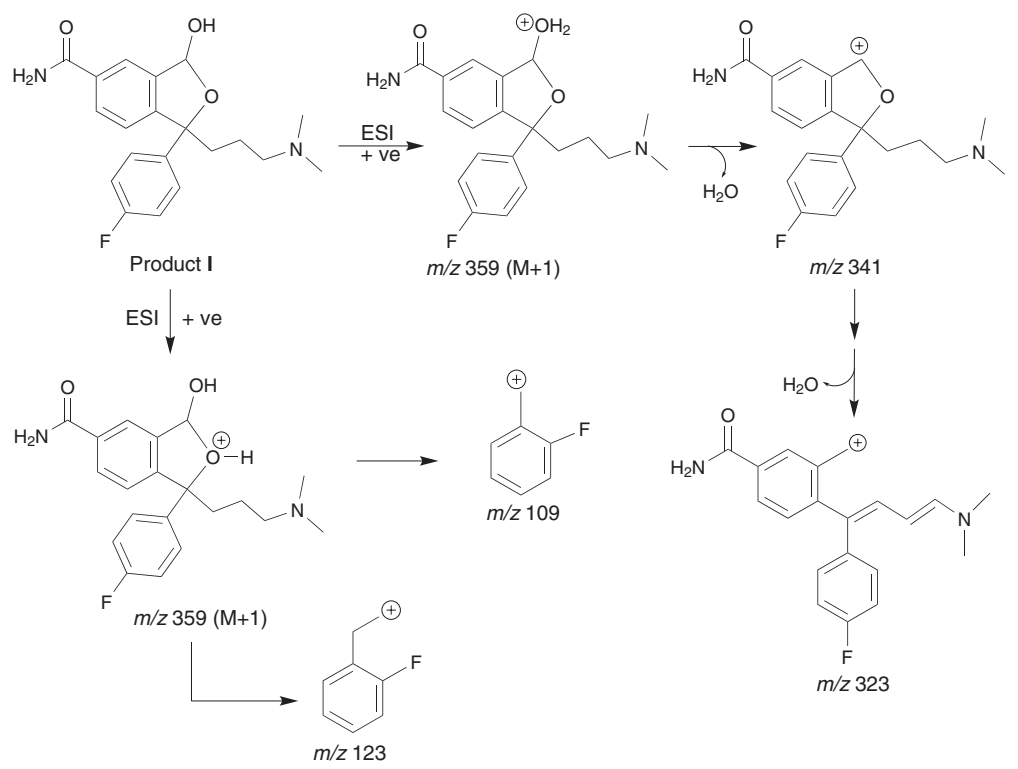

Figure 7. Proposed mass fragmentation pattern of product $\mathbf{I}$.

scan of $\mathbf{I}$ at $\mathrm{m} / \mathrm{z} 341$ which was proposed to form from the parent ion $(\mathrm{m} / \mathrm{z} 358.54)$ by loss of a $\mathrm{H}_{2} \mathrm{O}$ molecule ( $18 \mathrm{amu}$ ) triggered by protonation at $-\mathrm{OH}$ group introduced in the furan ring. Further loss of a $\mathrm{H}_{2} \mathrm{O}$ molecule from $\mathrm{m} / z 341$ through rearrangement was responsible to form another fragment at $m / z$ 323. Fragment peaks at $m / z 109$ and 123 similarly as in LC-MS scans of CTL and II indicated that the $p$-fluorophenyl moiety is intact. Based on these results and discussions, the most possible structure for I was proposed to be 1-(3-dimethylaminopropyl)-1-(4fluorophenyl)-3-hydroxy-1,3-dihydroisobenzofuran-5carboxylic acid amide (3-hydroxy citalopram carboxamide) (Figure 1).

The product IV was formed in acidic medium under photolytic conditions. Its even molecular mass (340 amu) indicated even number of nitrogen atoms in it. Elimination of both the nitrogen atoms from the drug molecule is not possible under the photolytic conditions which implied that both the nitrogen atoms of the drug were intact in IV. Further, a difference of 16 amu with respect to mass of the drug indicated that $\mathbf{I V}$ was formed by addition of an oxygen atom to the drug molecule. Under the photolytic conditions, this addition of an oxygen atom is expected to produce an $\mathrm{N}$-oxide product through photoxidation at nitrogen of either the tertiary amino or nitrile group resulting in two possible structures, i.e., citalopram $\mathrm{N}$-oxide (IVa) and citalopram cyano N-oxide (IVb) (Figure 8). IVb seemed to be less probable because nitrogen of $\mathrm{C} \equiv \mathrm{N}$ is more electronegative (sp hybridized) in comparison to that of tertiary amine ( $s p^{3}$ hybridized). It makes the photoxidation of $\mathrm{C} \equiv \mathrm{N}$ less probable than tertiary amine. The LC-MS ${ }^{2}$ scan of IV (Figure 5C) showed fragment peaks at $\mathrm{m} / 2323,305,279,228,123,109$ and 83. The mass fragmentation pattern of $\mathbf{I V}$ is proposed in Figure 8. The fragment of $\mathrm{m} / 2323,305$ were possibly formed by loss of two water molecule one after the other from $\mathrm{m} / \mathrm{z}$ 341 triggered by protonation of oxygen of the $\mathrm{N}$-Oxide at tertiary amine. However, no such fragments can be formed if photoxidation occurs at $\mathrm{C} \equiv \mathrm{N}$ group. Further, the peaks at $m / z, 123,109$ and 83 were noted similarly as in $\mathrm{MS}^{2}$ scan of the drug, I and II indicating that the $p$-fluorophenyl ring was intact. Hence, product IV was proposed to be citalopram N-oxide, a known impurity (Figure 1) which is formed by photoxidation of tertiary amino nitrogen of CTL.

\section{Degradation pathways}

Based on the above results, the degradation pathways of CTL under hydrolytic and photolytic conditions are outlined in Figure 9. The drug was hydrolysed to product II through the well-known hydrolytic reaction of nitriles to amides in aqueous media. ${ }^{3}$ The product $\mathbf{I}$ could be formed from II through substitution reaction at methylene of dihydrobenzofuran ring under the influence of air and light in aqueous environment via a tetrahydrofuran hydroperoxide intermediate. ${ }^{4}$ Alternatively, the product I could be formed directly from the drug through some unknown route. The drug underwent photoxidation at nitrogen of the tertiary amine to form the product IV.

\section{Method validation}

The response for the drug was strictly linear in the concentration range of 5-500 $\mu \mathrm{g} \mathrm{mL}^{-1}$. The mean $( \pm$ SD) of slope, intercept and correlation coefficient are 

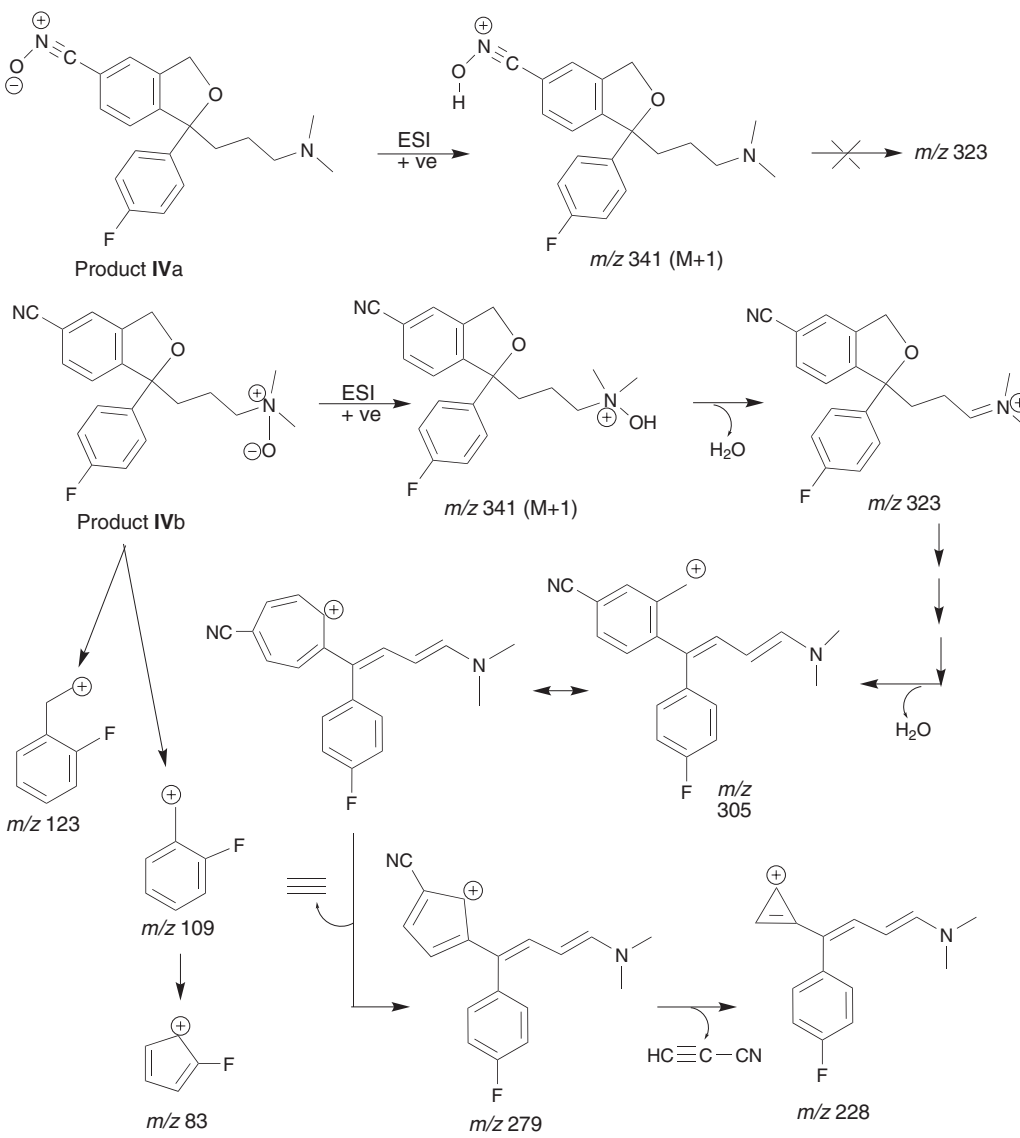

Figure 8. Proposed mass fragmentation pattern of product IV.

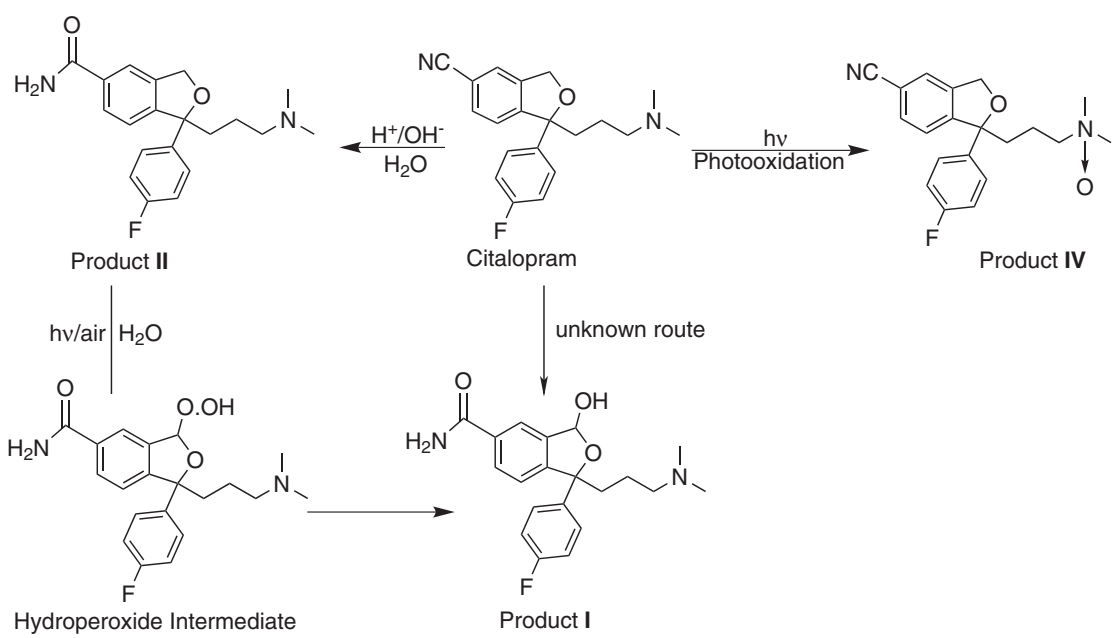

Figure 9. Degradation pathways of CTL.

$98333( \pm 1464), 84370( \pm 13776)$ and $0.9998( \pm 0.0002)$, respectively. The method was sufficiently precise for the drug over the selected concentration range. The RSD values of intra-day and inter-day precision studies were $<1$ and $<3 \%$, respectively (Table 3 ). Excellent recoveries (88-97\%) were achieved at each added concentration of the drug (Table 4) indicating the method to be sufficiently accurate for quantification of CTL. The LOD and LOQ for the drug
Table 3. Intra-day and inter-day precision studies

\begin{tabular}{lcc}
\hline $\begin{array}{l}\text { Actual conc. } \\
\left(\mu \mathrm{g} \mathrm{mL}^{-1}\right)\end{array}$ & \multicolumn{2}{c}{ Measured conc. $\left(\mu \mathrm{g} \mathrm{mL}^{-1}\right) ; \% \mathrm{RSD}$} \\
\cline { 2 - 3 } & Intra-day $(n=6)$ & Inter-day $(n=3)$ \\
\hline 40 & $40 ; 0.58$ & $41 ; 2.59$ \\
80 & $80 ; 0.24$ & $80 ; 1.23$ \\
160 & $159 ; 0.32$ & $160 ; 1.12$ \\
\hline
\end{tabular}


Table 4. Recovery studies

\begin{tabular}{lcc}
\hline $\begin{array}{l}\text { Fortified conc. } \\
\left(\mu \mathrm{gL}^{-1}\right)\end{array}$ & $\begin{array}{c}\text { Calculated conc. } \\
\left(\mu \mathrm{g} \mathrm{mL} \mathrm{mL}^{-1}\right) ; \% \operatorname{RSD}(n=6)\end{array}$ & $\begin{array}{c}\text { Recovery } \\
(\%)\end{array}$ \\
\hline 40 & $35 ; 2.34$ & 88 \\
80 & $73 ; 0.77$ & 91 \\
160 & $155 ; 0.95$ & 97 \\
\hline
\end{tabular}

were found to be $1 \mu \mathrm{g} \mathrm{mL}^{-1}$ and $5 \mu \mathrm{g} \mathrm{mL}^{-1}$, respectively. The resolution of the drug peak from the nearest resolving peak was always $>5$ indicating the method specific to the drug. The method was also selective to degradation products as all the peaks were pure, which was proved through PDA purity studies. Good separations and recoveries were always achieved during robustness studies, indicating that minor deviations in chromatographic conditions do not affect quantification of CTL.

\section{Conclusions}

A systematic forced degradation study on citalopram hydrobromide was performed under the conditions of hydrolysis, oxidation, dry heat and photolysis. Subsequently, an isocratic stability-indicating HPLC-UV method was developed to study the degradation behaviour of the drug under various forced conditions. The drug was found unstable in hydrolytic and photolytic conditions in all media. However, it proved stable to heat and light in solid state. In total five degradation products $(\mathbf{I}-\mathbf{V})$ were formed. The product II was isolated and characterized as citalopram carboxamide which is a known impurity. The products I and IV were characterized on the basis of mass fragmentation pattern outlined through LC-MS and LC-MS ${ }^{2}$ studies. The product IV was characterized as citalopram $\mathrm{N}$-oxide which also a known impurity. However, the product I was characterised as 3-hydroxy citalopram carboxamide. The products III and $\mathbf{V}$ were not characterized due to their poor ionization in mass detector. However, characterization of these products may be assisted by use of more advanced techniques like preparative HPLC or preparative LC-MS. Based on the results, degradation pathways were proposed. The method was validated in accordance with the ICH guidelines for determination of the drug. The method proved linear, precise, accurate and robust for quantification of citalopram with sufficient sensitivity. It was specific to the drug and selective for each degradation product.

\section{Acknowledgement}

The authors are thankful to Prof. Saranjit Singh, Head of Department of Pharmaceutical Analysis, National Institute of Pharmaceutical Education and Research, SAS Nagar, India of for facilitating photodegradation and LC-MS studies and to Ind-Swift Laboratories, Panchkula (India) for providing citalopram hydrobromide as a generous gift to conduct the study.

\section{References}

1. Hyttel, J.; Prog. Neuro-Psychoph. 1982, 6, 277; Pallanti, S.; Quercioli, L.; Paiva, R. S.; Koran, L. M.; Eur. Psych. 1999, 14, 101.

2. Egashira, N,; Matsumoto, Y.; Mishima, K.; Iwasaki, K.; Fujioka, M.; Matsushita, M.; Shoyama, Y.; Nishimura, R.; Fujiwara, M.; Pharmacol. Biochem. Behav. 2006, 83, 161.

3. March, J.; Advanced Organic Chemistry: Reactions, Mechanisms and Structure, $4^{\text {th }}$ ed., Wiley Interscience: New York, 1992, pp. 887.

4. Badger, G. M.; The Chemistry of Heterocyclic Compounds, $1^{\text {st }}$ ed., Academic Press: New York, 1961.

5. Molcan Corporation, available: www.molcan.com/impurity.htm accessed in October 2007; LGC Standards - Global quality management solutions for the laboratory, available: www. lgcstandards.com Pharmaceutical Reference Substance and Impurities Newsletter 2007, 3.

6. Raman, B.; Sharma, B. A.; Ghugare, P. D.; Karmuse, P. P.; Kumar, A.; J. Pharm. Biomed. Anal. 2009, 50, 377.

7. ICH Q3A(R2) Impurities in New Drug Substances, In International Conference on Harmonization, IFPMA, Geneva, 2006; ICH Q3B(R2) Impurities in New Drug Products. International Conference on Harmonization, IFPMA, Geneva, 2006.

8. ICH Q1A(R2) Stability Testing of New Drug Substances and Products, In International Conference on Harmonization, IFPMA, Geneva, 2003.

9. Kwon, J.-W.; Armbrust, K. L.; Environ. Toxicol. Chem. 2005, 24, 1618; Narasa, A.; thesis available: www.eprints. csirexplorations.com/46/1/Abstract.docx, 2008, chapter 3 .

10. Meng, Q. H.; Gauthier, D.; Clin. Biochem. 2005, 38, 282; Zhang, R.; Xiao, S.; Xu, H.; Huang, R.; Xia, Z.; Chinese J. Anal. Chem. 2006, 34, 1384; Kosel, M.; Eap, C. B.; Amey, M.; Baumann, P.; J. Chromatogr. B: Biomed. Sci. Appl. 1998, 719, 234; Greiner, C.; Hiemke, C.; Bader, W.; Haen, E.; J. Chromatogr. B 2007, 848, 391; Andersen, S.; Halvorsen, T. G.; Pedersen-Bjergaard, S.; Rasmussen, K. E.; Tanum, L.; Refsum, H.; J. Pharm. Biomed. Anal. 2003, 33, 263; Nevado, J. J. B.; Llerena, M. J. V.; Cabanillas, C. G.; Robledo, V. R.; J. Chromatogr. A 2006, 1123 , 130; Pistos, C.; Panderi, I.; Atta-Politou, J.; J. Chromatogr. B 2004, 810, 235; Rao, R. N.; Raju, A. N.; Nagaraju, D.; J. Pharm. Biomed. Anal. 2006, 41, 280; Juan, H.; Zhiling, Z.; Huande, L.; J. Chromatogr. B 2005, 820, 33; Kristoffersen, L.; Bugge, A.; Lundanes, E.; Slørdal, L.; J. Chromatogr. B: Biomed. Sci. Appl. 
1999, 734, 229; Macek, J.; Ptacek, P.; Klíma, J.; J. Chromatogr. B: Biomed. Sci. Appl. 2001, 755, 279.

11. European Pharmacopoeia, $6^{\text {th }}$ ed., 2009, Suppl. 6.4, pp. 4605; United States Pharmacopoeia 2005, 31, 1778.

12. ICH Q1B Photostability Testing of New Drug Substances and Products, In International Conference on Harmonization, IFPMA, Geneva, 1996.
13. ICH Q2(R1) Validation of Analytical Procedures: Text and Methodology, In International Conference on Harmonization, IFPMA, Geneva, 2005.

14. Mullera, C.; Vogta, S.; Goerkea, R.; Kordonb, A.; Weinmanna, W.; Forensic Sci. Int. 2005, 113, 415.

Submitted: July 1, 2010

Published online: January 27, 2011 